\title{
Constitutional Norms for All Time?
}

\section{General Entrenchment Clauses in the History of European Constitutionalism}

\author{
Michael Hein ${ }^{*}$
}

\begin{abstract}
'General entrenchment clauses' are constitutional provisions that make amendments to certain parts of a constitution either more difficult to achieve than 'normal' amendments or even impossible, i.e., legally inadmissible. This article examines the origins of these clauses during the American Revolution (1776-77), their migration to the 'Old World', and their dissemination and differentiation on the European continent from 1776 until the end of 2015. In particular, the article answers three questions: (1) When, and in which contexts, did general constitutional entrenchment clauses emerge? (2) How have they migrated to and disseminated in Europe? (3) Which constitutional subjects do such clauses protect, and thus, which main functions do they aim to fulfil?
\end{abstract}

Keywords: constitutional amendments, constitutional law, constitutional politics, constitutionalism, entrenchment clauses, eternity clauses.

\section{A Introduction}

With a few exceptions, ${ }^{1}$ modern constitutions are generally entrenched, i.e., harder to amend than ordinary laws. Most notably, this is achieved by requiring increased majorities in parliament, the approval by two successive parliaments (i.e., the need for intervening elections), or an additional referendum. However, many constitutions take one or two further steps and contain additional entrenchment clauses. These are provisions that make amendments to certain parts of a constitution or amendments under certain circumstances either more difficult than 'normal' amendments or even impossible, in other words, legally inadmissi-

* $\quad$ Adult Education Center Altenburger Land, Altenburg, Germany. Email: mail@michaelhein.de. All cited websites were visited on June 18, 2018. Unless stated otherwise, all references to constitutions in this article are taken from M. Hein, The Constitutional Entrenchment Clauses Dataset, Göttingen 2018, http://data.michaelhein.de. All translations are by the author.

1 As of June 2018, these are the constitutions of New Zealand (1987), Papua New Guinea (1975), and Swaziland (2005), and the constitutional law of the United Kingdom and Israel (both of which are not codified in single documents). 
ble. ${ }^{2}$ Today, such clauses are common in every world region and in all types of political regimes. Approximately, four of every five national constitutions valid at the end of 2015 contain at least one entrenchment clause.

Some of those provisions apply only temporally, i.e., for a limited period of time. For instance, Art. 110, § 6 of the Greek Constitution of 1975 bans constitutional amendments "before the lapse of five years from the completion of a previous revision". Other clauses are valid only situationally, i.e., under certain 'extraconstitutional' circumstances, such as siege, emergency, war, or - in monarchies regency. A typical example is Art. 115 of the 1868 Constitution of Luxembourg (as amended in 1998): "During a regency, no change can be made to the Constitution concerning the constitutional prerogatives of the Grand Duke, his status as well as the order of succession."

In contrast, general entrenchment clauses refer to any conceivable amendment of a given constitutional order. Two types of such provisions can be differentiated. First, 'general prohibitions of amendments' - commonly also referred to as 'unamendable provisions', 'eternity clauses' or 'super-entrenchment clauses'3 entirely ban any changes to a certain constitutional subject, whether a provision, principle, or even the 'spirit' of the whole constitution. Second, 'general constraints on amendments' are 'selective rigidity mechanisms', ${ }_{4}^{4}$ which differentiate two or more groups of constitutional subjects, for which differently rigid amendment rules apply.

This article examines the origins of these clauses during the American Revolution (1776-77), their migration to the 'Old World', and their dissemination and differentiation on the European continent from 1776 until the end of 2015..$^{5}$ Although the general entrenchment clauses were developed as early as with the very beginnings of modern constitutionalism in North America in 1776-77 and a general prohibition of amendments was codified in a European national constitution already in 1798, it was only after World War II that both types of general entrenchment clauses became widespread all over in Europe. From the various concepts and metaphors in the study of comparative constitutional law and legal history, such as 'transplants', 'borrowing', 'diffusion', 'transfer', or 'reception', this article uses the very open concept of 'migration', since this is able "to capture

2 P. Suber, The Paradox of Self-Amendment: A Study of Logic, Law, Omnipotence, and Change. New York, Lang, 1990, p. 75. For a typology of constitutional entrenchment clauses, see M. Hein, 'Impeding Constitutional Amendments: Why Are Entrenchment Clauses Codified in Contemporary Constitutions?', Acta Politica, Vol. 54, No. 2, 2019, pp. 196-224, at p. 198 f., available at: https://doi.org/10.1057/s41269-018-0082-4.

3 Suber, 1990, p. 129.

4 Y. Roznai, Unconstitutional Constitutional Amendments: The Limits of Amendment Powers, Oxford, Oxford University Press, 2017, p. 168.

5 For the origins, differentiation, and global migration of all types of constitutional entrenchment clauses in the history of modern constitutionalism, see M. Hein, 'Entrenchment Clauses in the History of Modern Constitutionalism', Legal History Review, Vol. 86, No. 3-4, 2018, pp. 434-481. 
more accurately the complex dynamic of cross-constitutional exchanges" ${ }^{6}$ Generally, the migration of constitutional ideas, principles, and provisions describes:

all movements across systems, overt or covert, episodic or incremental, planned or evolved, initiated by the giver or receiver, accepted or rejected, adopted or adapted, concerned with substantive doctrine or with institutional design or some more abstract or intangible constitutional sensibility or ethos. ${ }^{7}$

Given the comprehensive approach of this study, which is necessarily unable to provide in-depth analyses of all observed cases, this seems to be a reasonable concept.

This article will particularly consider the following research questions:

1st When, and in which contexts, did general constitutional entrenchment clauses emerge?

2nd How have they migrated to and disseminated in Europe?

3rd Which constitutional subjects do such clauses protect, and thus, which main functions do they aim to fulfil?

With regard to the third research question, this article applies a concept provided by the legal historian Horst Dippel. According to this concept, modern constitutionalism is characterized by ten 'essentials': (1) popular sovereignty, (2) the foundation of a constitution on universal principles, (3) a declaration of rights, (4) limited government, (5) the supremacy of the constitution, (6) representative government, (7) the separation of powers, (8) accountability and responsible government, (9) an independent judiciary, and (10) an orderly procedure for amending the constitution. ${ }^{8}$ As will be shown, the main function that both general prohibitions of and general constraints on amendments have assumed during the history of modern constitutionalism is the protection of those essentials.

Empirically, this article uses the Constitutional Entrenchment Clauses Dataset (CECD) ${ }^{9}$ This dataset comprises the entrenchment clauses (and their changes) in 860 written national constitutions from 1776 until the end of 2015. It is presumed that the list is exhaustive of all national constitutions globally during that

6 V. Perju, 'Constitutional Transplants, Borrowing, and Migrations', in M. Rosenfeld \& A. Sajó (Eds.), The Oxford Handbook of Comparative Constitutional Law, Oxford, Oxford University Press, 2012, pp. 1304-1327, p. 1307.

7 N. Walker, 'The Migration of Constitutional Ideas and the Migration of the Constitutional Idea: The Case of the EU', in S. Choudhry (Ed.), The Migration of Constitutional Ideas, Cambridge, Cambridge University Press, 2006, pp. 316-344, at 320 f. See also Perju, 2012, pp. 1306-1308; S. Choudhry, 'Migration as a New Metaphor in Comparative Constitutional Law', in S. Choudhry (Ed.), The Migration of Constitutional Ideas, Cambridge, Cambridge University Press, 2006, pp. 1-35; F. Schauer, 'On the Migration of Constitutional Ideas', Connecticut Law Review, Vol. 3, 2005, pp. 907-919.

8 H. Dippel, 'Modern Constitutionalism: An Introduction to a History in Need of Writing', Legal History Review, Vol. 73, 2005, pp. 153-170, at 155 f.

9 M. Hein, The Constitutional Entrenchment Clauses Dataset, Göttingen, University of Göttingen, 2018, available at: http://data.michaelhein.de. 
period. ${ }^{10}$ As a matter of course, it is not easy to identify concrete migration paths between constitutional orders. However, the CECD provides an almost complete picture of the relevant textual developments. In many instances, it allows the observation of not only reception paths but also several 'migration waves', defined as the adoption (or adaption) of a constitutional idea, principle, or provision by a group of polities in one world region during a limited period of time.

The following Section B will analyze the emergence of modern constitutionalism and the invention of the 'amending power' in North America at the end of the 18th century. This provides the context for the invention of both types of general entrenchment clauses. In Section $C$, the emergence of those clauses, their migration to Europe, and their dissemination and differentiation in Europe will be examined. In concluding Section D, the study's main findings will be summarized.

\section{B The Invention of the 'Amending Power' in North America}

Modern constitutionalism emerged during the "great period of constitutional reflection in North America"11 at the end of the 18th century. This development provided the background against which the idea of additional entrenchment clauses was developed. In essence, modern constitutionalism was based on four ideas:

1st 'the people' are free to choose their political order;

2nd such an order must establish the key institutions of the state but also grant individuals certain rights against the state;

3rd the rules constituting the political order have primacy over all other legal norms; and

4th those rules must be codified in a single, written, legal document.

These ideas stemmed from two sources. The first was British constitutional thought was developed since the 17th century, especially during the Cromwellian

10 The CECD includes all constitutions of (formally) independent states from 1776 until 2015, including constitutional charters (such as the French charters of 1814 and 1830) or constitutional laws (such as the French constitutional laws of 1875 and 1940), as long as they substantively functioned as constitutions. The dataset also comprises the constitutions of the North American states before the federal US constitution came into effect in 1788 (or until the accession of each respective state to the USA), as well as the constitutions of the German states before the establishment of the North German Federation and the German Empire in 1867/71 and, after 1945, before the foundation of the Federal Republic of Germany and the German Democratic Republic in 1949. The constitutions of federation member states are not included. Changes regarding entrenchment clauses in existing constitutions, i.e., deletions, modifications, or new introductions of entrenchment clauses, are also included.

11 G. Stourzh, 'Constitution: Changing Meanings of the Term from the Early Seventeenth to the Late Eighteenth Century', in T. Ball \& J.G.A. Pocock (Eds.), Conceptual Change and the Constitution, Lawrence, University Press of Cansas, 1988, pp. 35-54, at 38. 
Era (1653-1659) and the 'Glorious Revolution' (1688). ${ }^{12}$ A century later, the American Revolution turned the principles of British 'parliamentary sovereignty' and the 'rights of Englishmen' against the British rulers of the colonies. ${ }^{13}$ This relied on a second source: the dual tradition of the colonial 'Charters', i.e., the legal documents issued by the British Crown, and the 'Compacts' concluded by the colonists themselves. Both kinds of documents had established the rules under which a colony was to be governed and the relationship between that colony and the metropolitan power. ${ }^{14}$

The combination of these sources engendered the concept of the constituent power of the people: the right to adopt a constitution exercised by a representative 'constitutional convention'. Furthermore, it led to the hierarchical differentiation of constitutional (fundamental) law and statutory law, the latter being adopted and executed by the constituted power of the state authorities. ${ }^{15}$ Finally, it implied the enablement of constitutional amendments: if the basic law was no longer understood as 'God-given' but as man-made (much later, also womanmade), the people also had the right to change this law.

This led to two innovative solutions. The constitutions of Pennsylvania (1776), Vermont (1777), Georgia (1777), Massachusetts (1780), and New Hampshire (1784) allowed for constitutional change by a new constitutional convention, i.e., by recalling the constituent power of the people. In contrast, the 1776 constitutions of Delaware and Maryland, as well as the 1778 Constitution of South Carolina, established an amending power within the existing constitutional order. This allowed state authorities themselves (such as the parliament and the head of state, but also the 'people' by means of a referendum ${ }^{16}$ ) to alter the constitutional text. However, amendments were entrenched, either by demanding increased majorities in the parliamentary chambers (Delaware and South Carolina) or by requiring the consent of two succeeding parliaments (Maryland).

This conceptualization of the constituent, constituted, and amending powers was soon carried to France. From 1776, a delegation of the Continental Congress, headed by Benjamin Franklin, had been posted in Paris to secure French support in the war against England. In 1783, Franklin initiated a translation and publication of all American state constitutions and the 'Articles of Confederation', which became famous in France, soon. ${ }^{17}$ Based on this knowledge, Emmanuel Joseph

12 See W.P. Adams, The First American Constitutions. Republican Ideology and the Making of the State Constitutions in the Revolutionary Era, Chapel Hill, University of North Carolina Press, 1980, pp. 8-13; C. Borgeaud, Adoption and Amendment of Constitutions in Europe and America, New York, Macmillan, 1895, p. $137 \mathrm{f}$.

13 See Adams, 1980, p. 26.

14 See D.S. Lutz, The Origins of American Constitutionalism, Baton Rouge, Louisiana State University Press, 1988, pp. 23-49.

15 See Adams, 1980, pp. 63-66, p. 75 f., pp. 96-98, 135-137; W.F. Dodd, The Revision and Amendment of State Constitutions, Baltimore, John Hopkins Press, 1910, p. 22.

16 German jurisprudence literally speaks of "the people as a state organ" (das Volk als Staatsorgan); E.-W. Böckenförde, Constitutional and Political Theory: Selected Writings, Oxford, Oxford University Press, 2017, p. 181.

17 L.-A. de La Rochefoucauld (Ed.), Constitutions des treize États-unis de l'Amérique, Paris, Pierres, Pissot, 1783. See Borgeaud, 1895, p. 21. 
Sieyès later developed his similar concept of pouvoir constituant and pouvoir constitué, although he "thought himself the inventor of it" ${ }^{18}$

Due to its obvious practical advantages, the amending power soon gained acceptance on both sides of the Atlantic Ocean. It allows for constitutional flexibility to react to changing social circumstances and to correct constitutional imperfections. Thus, it enhances the stability (i.e., the survival capability) of a constitution. Furthermore, it enables constitutional alteration without changing the constitutional identity, in other words, an evolutionary development of the constitution. ${ }^{19}$ However, with regard to allowing constitutional change by state authorities, the questions arose of whether and how this path should be constrained. It potentially enabled the representatives to take far-reaching, fundamental decisions beyond the scope of their authority. As early as 1758, the Swiss legal scholar Emer de Vattel had flagged the dangers of allowing state authorities to amend the constitution: "it is from the constitution that those legislators derive their power: how then can they change it without destroying the foundation of their own authority?"20 Against this background, "the belief that amendment was inevitable, paradoxically, gave rise to efforts at entrenchment." 21 Thus, the idea of additional general entrenchment clauses emerged.

\section{The Invention, Migration, and Differentiation of General Entrenchment Clauses}

\section{The Emergence of General Entrenchment Clauses in North America}

Although general entrenchment clauses were developed in North America, the concept of formal unamendability had some antecedents in Europe. In ancient Greece, lawgivers used entrenchment clauses as "safeguards to prevent the powerful from altering the law to suit their wishes", 22 and for "strategic purposes in both international and domestic contexts". ${ }^{23}$ Thus, such clauses are documented

18 Ibid., p. 23; see also Emmanuel Joseph Sieyès, 'What Is the Third Estate?', in M. Sonenscher (Ed.), Sieyès: Political Writings: Including the Debate Between Sieyès and Tom Paine in 1791, Indianapolis, Hacket, 2003, pp. 92-162.

19 See Roznai, 2017, p. 4 f.; H. Dreier, Gilt das Grundgesetz ewig? Fünf Kapitel zum modernen Verfassungsstaat, München, Carl Friedrich von Siemens Stiftung, 2009, p. 45; M. Schwartzberg, Democracy and Legal Change, Cambridge, Cambridge University Press, 2007, pp. 193-210.

20 E. de Vattel, The Law of Nations; Or Principles of the Law of Nature, Applied to the Conduct and Affairs of Nations and Sovereigns, 6th ed., Philadelphia, T. \& J. W. Johnson, 1844, p. 11, emphasis in original. Vattel's work was probably the main theoretical source for the invention of the amending power in North America: see ibid., pp. 9-11; Stourzh, 1988, pp. 35, 45; J.S. Reeves, 'The Influence of the Law of Nature Upon International Law in the United States', American Journal of International Law, Vol. 3, 1909, pp. 547-561, at 552.

21 Schwartzberg, 2007, p. 7.

22 E.M. Harris, 'Solon and the Spirit of the Law in Archaic and Classical Greece', in E.M. Harris (Ed.), Democracy and the Rule of Law in Classical Athens: Essays on Law, Society, and Politics, Cambridge, Cambridge University Press, 2006, p. 3, p. 22. 
for many poleis, with many setting quite drastic punishments, such as outlawry, expropriation, or expatriation, for actors breaching them. ${ }^{24}$

In Early Modern Europe, there are four known cases of unamendable provisions and laws. The first two emerged during the English Civil War and the temporary abolition of the English monarchy. Both the 'Agreement of the People' (1647/49) and the 'Instrument of Government' (1653) contained provisions that some scholars have interpreted as unamendable. ${ }^{25}$ Less disputed is the 1665 'King's Law' (Lex Regia or Kongeloven) issued by Frederick III, the King of Denmark and Norway, which formed the absolutist constitution of both countries. In its preamble, the law was declared 'irrefutable' (uimodsigelig) and valid 'for everlasting time' (till cevig tiid). ${ }^{26}$ Finally, the Hungarian "Act VIII on the liberties and privileges of noblemen" (1741) was claimed to be unamendable. ${ }^{27}$

In the late 17th century, John Locke brought the concept of formal unamendability from Britain to its colonies. The 1669 'Fundamental Constitutions of Carolina', i.e., the colony's charter written by Locke, was declared in its concluding Section 120 to "be and remain the sacred and unalterable form and rule of government of Carolina forever". ${ }^{28}$ Eight years later, the leaders of the colony of 'West New Jersey' resolved the "Concessions and Agreements of the Proprietors, Freeholders and Inhabitants of the Province of West New Jersey in America". This document included a 'Charter' of "the common law or fundamental rights", which was declared unamendable in Chapter $13 .^{29}$

Whereas both the Carolina and West New Jersey charters remained traditional insofar as they contained no amendment rules, the 1701 Charter of Pennsylvania advanced one step further. It was the first basic law to combine an amending power within the existing constitutional order (i.e., without recurrence to the constituent power of the people) with a general prohibition of amendments:

Art. VIII: AND no Act, Law or Ordinance whatsoever, shall at any Time hereafter, be made or done, to alter, change or diminish the Form or Effect of this Charter, or of any Part or Clause therein, contrary to the true Intent and Meaning thereof, without the Consent of the Governor for the Time being, and Six Parts of Seven of the Assembly met.

BUT because the Happiness of Mankind depends so much upon the Enjoying of Liberty of their Consciences as aforesaid, [...] the First Article of

24 For more details, see Harris, 2006, pp. 21-24; Schwartzberg, 2007, pp. 31-70; D.M. Lewis, 'Entrenchment-Clauses in Attic Decrees, in P.J. Rhodes (Ed.), Selected Papers in Greek and Near Eastern History, Cambridge, Cambridge University Press, 1997, pp. 136-149. See Schwartzberg, 2007, pp. 86 f., pp. 101-105.

26 See L.B. Orfield, The Growth of Scandinavian Law, Philadelphia, University of Pennsylvania Press, 1953, p. 21.

27 See Z. Szente, 'The Historic Origins of the National Assembly in Hungary', Historia Constitucional, Vol. 8, 2007, pp. 227-244, at 239.

28 J. Locke, 'The Fundamental Constitutions of Carolina', in The Works of John Locke, Vol. 9, 12th ed., London, C. and J. Rivington, 1824, pp. 175-199, at 198.

29 The Concessions and Agreements of the Proprietors, Freeholders and Inhabitants of the Province of West New-Jersey, in America, [1677], available at: http://westjersey.org/ca77.htm. 
this Charter relating to Liberty of Conscience, and every Part and Clause therein, according to the true Intent and Meaning thereof, shall be kept and remain, without any Alteration, inviolably for ever [...]. ${ }^{30}$

After declaring independence from the British crown, similar combinations were used in the new constitutions of two former colonies in 1776: Delaware (which had been part of Pennsylvania until 1776) codified a general prohibition of amendments, while Maryland adopted a general constraint on amendments.

However, the modern history of general constitutional entrenchment clauses began somewhat paradoxically. The New Jersey Constitution, adopted on July 2 1776, did not include an amendment mechanism. Nevertheless, Art. 23 was an unamendable provision, obliging all parliamentarians to swear the following oath:

I, A. B., do solemnly declare, that [...] I will not assent to any law, vote or proceeding, which [...] shall annul or repeal that part of the third section in the Charter of this Colony, which establishes, that the elections of members of the Legislative Council and Assembly shall be annual; nor that part of the twenty-second section in said Charter, respecting the trial by jury, nor that shall annul, repeal, or alter any part or parts of the eighteenth or nineteenth sections of the same. ${ }^{31}$

This clause protected the annual elections to parliament (implying representative self-government of the people), trial by jury (implying an independent judiciary), and the positive and negative freedom of religion (including the separation of church and state). In other words, the entrenchment clause was designed to safeguard three essentials of modern constitutionalism.

Proclaimed on September 21 1776, Art. 30 of the Constitution of Delaware entitled the parliamentary chambers to adopt constitutional amendments by means of qualified majorities, but declared the entire "declaration of rights and fundamental rules", the name of the state, the bicameral parliament, representative democracy, the prohibition of slavery, and the separation of church and state unamendable. Although the genesis of this constitution is quite well-documented, the relevant documents and studies are silent on the emergence of the unamendable provision. ${ }^{32}$

The third constitution to codify a general prohibition of amendments was the 1777 Constitution of Georgia. Art. 3 stated that it "shall be an unalterable rule that the house of assembly shall expire and be at an end, yearly and every year, on the day preceding the day of election mentioned in the foregoing rule". Since constitutional 'alterations' were allowed only by convening a new constitutional convention (Art. 63), this clause obviously aimed to restrict the people's freedom of

30 Charter of Privileges Granted by William Penn, esq. to the Inhabitants of Pennsylvania and Territories, October 28, 1701, available at: http://avalon.law.yale.edu/18th_century/pa07.asp.

31 Unfortunately, little is known about the drafting of this constitution in the provincial congress. See Adams, 1980, p. 74.

32 See H.C. Reed, 'The Delaware Constitution of 1776’, Delaware Notes, 1930, pp. 7-42. 
decision. Again, we unfortunately know nothing about the emergence of that unamendable provision. ${ }^{33}$

In sum, these first three general prohibitions in the history of modern constitutionalism protected four essentials of modern constitutionalism: popular sovereignty, representative government, fundamental rights and freedoms, and an independent judiciary. In contrast, the first general constraint on amendments aimed to fulfil a different function. Art. 59 of the 1776 Constitution of Maryland raised two different hurdles for amendments:

That this Form of Government, and the Declaration of Rights, and no part thereof, shall be altered, changed, or abolished, unless a bill so to alter, change or abolish the same shall pass the General Assembly, and be published at least three months before a new election, and shall be confirmed by the General Assembly, after a new election of Delegates, in the first session after such new election; provided that nothing in this form of government, which relates to the eastern shore particularly, shall at any time hereafter be altered, unless for the alteration and confirmation thereof at least two-thirds of all the members of each branch of the General Assembly shall concur.

The second part of that article refers to several provisions in the constitution, in particular, that six of the 15 senators come from the Eastern Shore and nine from the Western Shore (Art. 15), that both parts of the country have their own treasurer (Art. 13) and own land register (Art. 51), and that the General Court of Maryland shall sit in both locations (Art. 56). The general constraint in Art. 59 was added to the original draft of the convention's constitutional committee during the plenary debate on November 6 1776, having been submitted by Solomon Wright, a delegate from the Eastern Shore. ${ }^{34}$

Unfortunately, the convention proceedings neither detail the debate on this proposal nor state the result of the vote thereon. Nevertheless, the general constraint's origin and success can be ascribed to the state's structure and the convention's composition. Maryland was characterized by a relatively sharp divide between a more progressive western part and a more conservative eastern part. The conservative delegates from the Eastern Shore, together with those from southern Maryland, not only controlled a majority in the convention but also all members of the constitutional committee. ${ }^{35}$ Through this dominance, the 'Easterners' were able to implement the afore-cited provisions, including the general constraint, which de facto provided them and their successors with a blocking minority in constitutional amendments affecting their regional interests.

Thus, that general constraint aimed to protect the balance of power between the two parts of Maryland. It was not a result of deliberation and consensus but, 1948, p. 98.

34 Proceedings of the Conventions of the Province of Maryland, Held at the City of Annapolis, in 1774, 1775, \& 1776, Baltimore, Lucas and Deaver, 1836, p. 328, p. 342.

35 See D. Friedman, The Maryland State Constitution, Oxford, Oxford University Press, 2011, p. 2. 
rather, of negotiation and power enforcement. As will be shown in Subsection C.III, general constraints of amendments were designed later, quite often to protect the balance of power between different regions, between the federal level and the member states in federations, and (albeit less frequently) between the central state and the regions or districts in unitary states. During the 20th century, however, the focus of the majority of general constraints converged with that of general prohibitions, i.e., protection of the essentials of modern constitutionalism.

\section{The Migration of General Prohibitions of Amendments to and within Europe}

The first European unamendable provision was codified in the short-lived 1798 Constitution of the Helvetic Republic. ${ }^{36}$ This constitution, imposed on Switzerland by Napoleon Bonaparte after the country's occupation, institutionalized an amending power within the existing constitutional order, which it combined with the following provision: "The form of government, whatever modifications it might experience, will always be a representative democracy" (Art. 2). Most probably, the idea of prohibiting certain amendments had migrated to France during the 1770s and 1780s as one of the political ideas of the American revolutionists (see Section B), but it was practically used for the first time in that Swiss constitution. Since it was imposed by a foreign power, however, it is anything but surprising that this first European unamendable provision did not become a model for any other constitution.

The next general prohibition in Europe was codified in Norway (1814). It is the oldest general prohibition worldwide that remains valid today and is, therefore, regarded as "the classic example [...] that is quoted on every occasion". ${ }^{37}$ In the original version of Art. 110 of the Norwegian Constitution, "an alteration must never be inconsistent with the principles of this fundamental law, but only concern modifications in particular cases, which do not alter the spirit of this Constitution." This was the first general prohibition worldwide that aimed to protect a constitution's 'spirit'. It "ranks among the most open-ended of all existing clauses on substantively non-amendable norms". ${ }^{38}$

It is not entirely clear how this unamendable provision emerged. ${ }^{39}$ Absent from the initial draft constitution of the constitutional assembly, it was proposed by a delegate late in the process, and its adoption was the very last action of the assembly. The proposal can probably be traced to the Danish Prince Christian Frederik, the regent at that time. The very idea of unamendability was common to Danish-Norwegian constitutional law from the 1665 'King's Law' (see subsection C.I). In addition, the constitutional assembly relied extensively on US consti-

36 In general, see J.C. Bluntschli, Geschichte des schweizerischen Bundesrechtes von den ersten ewigen Bünden bis auf die Gegenwart. Vol. 1: Geschichtliche Darstellung, Zürich, Meyer \& Zeller, 1849, pp. 452-458.

37 P. Häberle, 'Verfassungsrechtliche Ewigkeitsklauseln als verfassungsstaatliche Identitätsgarantien', in Y. Hangartner \& S. Trechsel (Eds.), Völkerrecht im Dienste des Menschen. Festschrift für Hans Haug, Bern, Haupt, 1986, pp. 81-102, at 84.

38 E. Smith, 'Old and Protected? On the "Supra-Constitutional" Clause in the Constitution of Norway', Israel Law Review, Vol. 44, 2011, pp. 368-388, at 373.

39 See ibid.; E. Holmøyvik \& D. Michalsen, Lcerebok i forfatningshistorie, Oslo, Pax 2015, pp. 365-369. 
tutional thought. The most influential lawyers in the assembly had been educated in Copenhagen, where they had studied both US and French constitutional developments. In addition, there is "physical evidence that American legislation was present during the Constitutional Assembly's session", ${ }^{40}$ most probably including a copy of the above-mentioned collection of US state constitutions. Thus, it is possible that the Norwegian framers combined the idea of unamendable provisions from North America with the general unamendability of the Danish-Norwegian 'King's Law', resulting in the innovative 'spirit clause'. However, only a very few European countries subsequently followed the Norwegian model and codified similar provisions: Greece (in its 1864, 1927, 1952, and 1968 constitutions) and the German states of Württemberg-Baden (1946) and the Saarland (1947).

In 1884, one of the most influential general prohibitions appeared in France. It was the first one - not only in Europe - to be introduced into an existing constitution by means of a simple amendment. After the breakdown of the Second French Empire in 1870 and the establishment of the 'Third Republic', more than a decade of quarrels ensued between monarchists and republicans over the nature of the new regime. After the republicans had finally prevailed, they reformed several aspects of the constitutional laws of 1875. Among other changes, they introduced the following unamendable provision: "The republican form of the government shall not be subject to revision" (Art. 8, new $\S 4$ of the Constitutional Law on the Organization of Government). Through this provision, the republicans aimed to avoid a third restoration of monarchy in the country (after previous restorations in 1804 and 1853) and end the long-lasting resistance of the monarchists after $1870 .{ }^{41}$ Similar provisions were also introduced in the subsequent constitutions of the Fourth and Fifth French Republics (1946 and 1958, respectively). ${ }^{42}$

In the first half of the 20th century, the French ban on reintroducing the monarchy was copied by several European countries, either after abolishing the monarchy (Portugal: 1911; Turkey: 1924; Albania: 1925;43 Greece: 1925; and Italy: 1947) or after gaining independence from an empire (Georgia: 1921). Greece (1975), Portugal (1976), and Turkey (1982) later expanded their unamendable provisions to include additional constitutional subjects. In addition to these cases, Cyprus (1960), the de facto state of the Turkish Republic of Northern Cyprus (1985), and Switzerland (1999) also codified unamendable provisions in their constitutions. The Portuguese Constitution of 1976 contained one of the

41 See Borgeaud, 1895, pp. 250, 253; Häberle, 1986, p. 88.

42 When decolonization began in the late 1950s, the French "republic clause" was copied by literally all African countries becoming independent from France and even some neighboring states with other former metropolitan powers. See Hein, Entrenchment Clauses, 2018, pp. $457 \mathrm{f}$.

43 The Albanian Republic only lasted three years. In 1928, President Ahmet Zogu declared himself the King. He introduced a new constitution that simply retained the general prohibition but now protected the monarchical form of government. In addition, the principles of democracy and national independence, the unitary state, the Albanian territory, and the capital of Tirana were declared unamendable; see M. Schmidt-Neke, Die Verfassungen Albaniens. Mit einem Anhang: Die Verfassung der Republik Kosova von 1990, Wiesbaden, Harrassowitz, 2009, pp. 31-36. 
most extensive unamendable provisions in the entire history of modern constitutionalism. ${ }^{44}$ Enacted after the 'Carnation Revolution', Art. 290 listed no less than 15 principles and provisions that were protected from any amendment. This list contained the republican form of government and several essentials of modern constitutionalism, but also:

f. the principle of collectivization of the main means of production and land and of natural resources and the abolition of monopolies and large estates;

g. the democratic planning of the economy; [...]

j. the participation by local people's organizations in local government [...].

One may ask whether topics of a certain political program can legitimately restrict the amending power. Practically, at least, the Portuguese political elite soon felt restricted in its policy options, particularly after the country's accession to the European Communities (the later European Union) in 1986. They finally decided to change the unamendable provision by means of a simple constitutional amendment. ${ }^{45}$ In the new version, lit. $\mathrm{j}$ was deleted, and lit. $\mathrm{f}$ and $\mathrm{g}$ were reformulated as follows:

f. the coexistence of the public, private and cooperative and social sectors in relation to the ownership of the means of production;

g. the requirement for economic plans, which shall exist within the framework of a mixed economy.

In contrast to their rather slow migration across Europe until 1945, unamendable provisions spread through two migration waves after 1945 and 1989. After World War II, ten of the 16 newly established German Länder in both parts of the country codified general prohibitions in their 1946 and 1947 constitutions. Above all, they aimed to protect democracy, fundamental rights and freedoms, and the republican form of government. These provisions embodied a reaction to experiences of the Nazi regime, particularly the so-called 'Enabling Act' (Ermächtigungsgesetz) that, in 1933, had created a (pseudo-)legal way to abolish the constitutional order of the 'Weimar Republic'. In addition, these clauses addressed the new threat to constitutionalism stemming from the Stalinist Soviet Union. Even in the Soviet Occupation Zone, where the newly established Socialist Unity Party of Germany did not yet control the whole political process, the Liberal and Christian Democratic parties were able to significantly influence constitution-making

44 This provision later also influenced former Portuguese colonies in Africa and East Asia. See Hein, Entrenchment Clauses, 2018, pp. 458.

45 J.E.M. Machado, 'The Portuguese Constitution of 1976. Half-life and Decay', in X. Contiades (Ed.), Engineering Constitutional Change: A Comparative Perspective on Europe, Canada and the USA, London, Routledge, 2013, pp. 273-298, at 275. For the normative problems of amending unamendable provisions, see R. Albert, 'Amending Constitutional Amendment Rules', International Journal of Constitutional Law, Vol. 13, 2015, pp. 655-685. 
processes and to enforce the enactment of unamendable provisions in the 1947 constitutions of Brandenburg, Mecklenburg, and Saxony-Anhalt. ${ }^{46}$

Art. 79, $\S 3$ of the 1949 Basic Law (Grundgesetz) of the Federal Republic of (Western) Germany followed this line by including the following amendment ban:

Amendments to this Basic Law affecting the division of the Federation into Länder, their participation on principle in the legislative process, or the principles laid down in Articles 1 [human dignity and human rights] and 20 [democracy, welfare state, rule of law, and federalism] shall be inadmissible. ${ }^{47}$

The Basic Law's creators were well aware that this clause would not prevent a renewed slide into dictatorship. As later first Minister of Justice Thomas Dehler observed during constitutional debates, it should merely ensure that any such dictatorship could not operate behind a 'mask of legality': an allusion to the 'Enabling Act' of 1933. Dehler continued: "No revolutionist should be able to claim that the Constitution was legally set aside." ${ }^{48}$ Although generally regarded as an 'eternity clause' (Ewigkeitsklausel), this provision is in fact a situational, rather than general, prohibition on amendments, since the concluding Art. 146 of the Basic Law provided a route for new constitution-making under certain circumstances: "This Basic Law shall cease to apply on the day on which a constitution freely adopted by the German people takes effect." However, the reunification of 1990 was not achieved by means of new constitution-making. Instead, the Basic Law was retained with an amendment to Art. 146 stating that "since the achievement of the unity and freedom of Germany", the Basic Law "applies to the entire German people". Therefore, Art. $79, \S 3$ has to be classified as a general constraint on amendments since then.

After the Berlin Wall fell in 1989, a second migration wave of general prohibitions spread through post-socialist Central and Eastern Europe and Central Asia. Similarly to postwar Germany, the countries in these regions adopted unamendable provisions "in light of a bitter experience and as a rejection of the sordid past” ${ }^{49}$ From Romania (1991) to Kosovo (2008), eleven post-socialist countries enacted constitutions with a variety of comprehensive general prohibitions. Such provisions especially protect the republican form of government, fundamental rights and freedoms, democracy, and the rule of law, but also subjects such as national independence or the welfare state. Thus, for instance, Art. 148 (2003 renumbered: Art. 152) of the 1991 Constitution of Romania states: Christian Democrats, resulting in a general constraint on amendments to the fundamental rights: see J. Frackowiak, Soziale Demokratie als Ideal. Die Verfassungsdiskussionen in Sachsen nach 1918 und 1945, Köln, Böhlau, 2004, pp. 254-270.

47 For the emergence of this provision, see Schwartzberg, 2007, pp. 153-192; Dreier, 2009, pp. 57-61.

48 Quoted from ibid., p. 59.

49 Roznai, 2017, p. 30. 
$\S 1$ : The provisions of the present Constitution concerning the national, independent, unitary, and indivisible character of the Romanian state, the Republic as the form of government, territorial integrity, the independence of the judicial system, political pluralism, and the official language may not be the object of a constitutional amendment.

$\S 2$ : Similarly, no amendment shall be adopted if it would result in the elimination of the fundamental rights and freedoms of citizens or of the guarantees of these rights and freedoms.

Since the Romanian Constitutional Court is obliged to review any proposal to amend the constitution, this general prohibition of amendments has considerably influenced the constitutional development of the country. ${ }^{50}$

\section{The Migration of General Constraints on Amendments to and within Europe}

In contrast to the general prohibitions of amendments, which had reached the European continent even before the turn of the 19th century, the first general constraints not appeared before the 1848-49 revolutions on the continent. First, the Bavarian King was forced to grant the parliament a restricted right to constitutional amendment initiatives. Whereas, in the original 1818 Constitution of Bavaria, this was the exclusive right of the monarch, the constitutional amendment of 1848 entitled the parliament to initiate revisions to certain parts of the constitution. Since amending provisions, regulating the monarchy, parliament, army, and public finances, as well as changing the amendment rules themselves, remained a privilege of the King, the 1848 amendment resulted in a general constraint on amendments. ${ }^{51}$

Second, the short-lived 1849 Constitution of the Grand Duchy of Mecklenburg-Schwerin (abolished in 1850) more purposefully established a general constraint on amendments. The constitution was a compromise between democrats and the archconservative nobility. ${ }^{52}$ Consequently, the constitution generally restricted the competences of the Grand Duke, who, for instance, had only a suspensive veto against laws, which the parliament could overrule by a two-thirds majority vote. The only exception was $\S 113$ regarding certain changes to the constitution, according to which amendments "to the constitutional rights of the head of state" and to the constitutional amendment rules required the Grand Duke's consent.

The Bavarian and Mecklenburg provisions were the first general constraints in monarchies (both entrenching the monarchical form of government) and the first to protect the amendment rules (including the general constraint). They, thus, functioned as a last resort of a monarchy facing the democratic threat of

50 See S. Ghergina \& M. Hein, 'Romania', in A. Fruhstorfer \& M. Hein (Eds.), Constitutional Politics in Central and Eastern Europe: From Post-Socialist Transition to the Reform of Political Systems, Wiesbaden, Springer VS, 2016, pp. 173-197.

51 See Borgeaud, 1895, p. 58.

52 See H. Pogge von Strandmann, 'The German Revolutions of 1848-1850 and the Sonderweg of Mecklenburg', in R.J.W. Evans and Id. (Eds.), The Revolutions in Europe 1848-1849: From Reform to Reaction, Oxford, Oxford University Press, 2002, pp. 99-133. 
revolution. Nevertheless, general constraints remained quite unpopular in Europe for a long time. Before 1989, they had only spread to eight other countries (plus the united German Empire), from France (1852) to Spain (1978). Outside the post-socialist region (see next in this subsection), only Liechtenstein introduced a new general constraint after 1989 (2003).

Three of these cases are particularly worth noting. First, Art. 78, $§ 2$ of the 1871 Constitution of the German Empire stated that those provisions

by which certain rights of individual members of the Federation in their relations to the whole are determined, can be amended only with the consent of the member of the Federation entitled to said rights.

Although there is no evidence of a reception of the US model, ${ }^{53}$ this provision obviously resembled the general constraint in Art. V of the US Constitution. ${ }^{54}$ Second, the 1944 Constitution of Iceland (Art. 79, § 2) remains both the first and only modern constitution worldwide to entrench Protestantism as the state religion.

Third, in 2003, Liechtenstein introduced a general constraint into its 1921 Constitution, establishing a special procedure allowing for abolition of the monarchy (Art. 113). Interestingly, this amendment was initiated by Prince HansAdam II and his son, Hereditary Prince Alois, themselves. Albeit entrenched by requiring absolute majorities in the parliament and in two referendums, it allows the monarchy to be abolished without the prince's consent (without which no other constitutional amendment is possible). ${ }^{55}$

After the Berlin Wall fell in 1989, general constraints on amendments spread to more than half of the post-socialist countries in Central and Eastern Europe and Central Asia. This migration wave reached 18 countries, from Bulgaria (1991) to Kyrgyzstan (2007). The general constraints in these countries protect a variety of contents, typically including the republican form of government and key essentials of modern constitutionalism, but also such topics as the territory, national independence, national culture, or the preservation of the environment. Some provisions are also designed to protect the balance of power between the central state and the member states of a federation, or between the central state and the districts. For example, Art. 131 of the 1991 Constitution of Macedonia, after an amendment adopted in 2001, declares that any amendment of

See M. Polzin, 'Constitutional Identity, Unconstitutional Amendments and the Idea of Constituent Power: The Development of the Doctrine of Constitutional Identity in German Constitutional Law', International Journal of Constitutional Law, Vol. 14, 2016, pp. 411-438, at 414; P. Laband, Das Staatsrecht des Deutschen Reiches, 4th ed., Tübingen, Mohr, 1901; P. Posener, Die Verfassung des Deutschen Reiches. Kommentar, Leipzig, Roßberg, 1903; 'Stenographischer Bericht der 11. Sitzung am 11. April 1871', in Deutscher Reichstag (Ed.), Stenographische Berichte über die Verhandlungen des Deutschen Reichstages. I. Legislatur-Periode. 1. Session 1871, Berlin, Norddeutsche Allgemeine Zeitung, 1871, pp. 159-162.

54 "[...] no State, without its Consent, shall be deprived of its equal Suffrage in the Senate."

55 See G. Winkler, Die Verfassungsreform in Liechtenstein. Verfassungsrechtliche Studien mit verfassungsvergleichenden und europarechtlichen Perspektiven, Wien, Springer, 2003. 
the articles on local self-government [...] shall require a two-thirds majority vote of the total number of Representatives, within which there must be a majority of the votes of the total number of Representatives who belong to the communities not in the majority in the population of Macedonia.

The post-socialist general constraints had various roots and causes. In some cases, they even emerged without any reference to foreign sources, deriving instead from an examination of national constitutional history. Particularly interesting in this respect is the Bulgarian Constitution of 1991. According to Arts. 158-163, changes to certain constitutional provisions and the adoption of a new constitution can only be made by a 'Grand National Assembly', which has to be elected especially for this purpose. This traces back to the first constitution of Bulgaria (1879), according to which any amendment could only be adopted through such a constitutional assembly. The first draft of the new constitution in 1991 restored that rule; however, during parliamentary debates, the constitutionmakers agreed that such a mechanism would be too inflexible. Therefore, they restrained the Grand National Assembly's area of competence. ${ }^{56}$

\section{Conclusion}

This study has examined the origins of general constitutional entrenchment clauses during the American Revolution (1776-77), their migration to the 'Old World', their dissemination and differentiation on the European continent, and their functions in modern constitutional orders. Although inevitably a tour d'horizon, this article has provided a broad historical picture of general entrenchment clauses in Europe. In sum, this study has produced four main findings:

First, the legal technique of prohibiting or constraining certain constitutional amendments has not been restricted to the initial contents and functions of such clauses. Instead, manifold subjects have been incrementally added. Historically, virtually no kind of constitutional provision or principle has not been protected at least once by a general entrenchment clause. Second, the differentiation of general entrenchment clauses led not only to a broader variety of entrenched topics but also to those clauses growing "in length, complexity, and detail" ${ }^{57}$ In Europe, the most extensive and complex general prohibitions and constraints are to be found in rather recent constitutions, such as those of Cyprus (1960), Portugal (1976), and Russia (1993). In addition, a considerable number of rather recent constitutions have included both types of general entrenchment clauses: Albania (1928), France (1946), Moldova (1994), Azerbaijan (1995), and Ukraine (1996).

Third, from their very first use, the main function of general prohibitions has been to protect the essentials of modern constitutionalism. Even the protection of the republican form of government, the constitutional principle most often protected by unamendable provisions (in 22 constitutions from 1798 to 2015),

56 See M. Hein, Verfassungskonflikte zwischen Politik und Recht in Südosteuropa: Bulgarien und Rumänien nach 1989 im Vergleich, Baden-Baden, Nomos, 2013, p. 102, pp. 109-111.

57 Roznai, 2017, p. 21. 
falls into this category, insofar as republicanism has often been understood as a modern counter-model to pre-modern monarchism. Although general constraints on amendments were initially - and, in many cases, are still today - designed to protect the balance of power between different regions, between the central state and the member states (in federations), between the central state and the regions or districts (in unitary states), or between different groups of powerful actors, the majority of general constraints in the European history of modern constitutionalism fulfil the same function as general prohibitions, i.e., the protection of the essentials of modern constitutionalism.

Forth, and finally, this article has shown that today, a general constitutional entrenchment clause is not "a very uncommon provision", 58 but instead a typical element of the majority of European constitutions. At the end of 2015, of all 57 national constitutions valid in Europe and post-socialist Central Asia, 16 constitutions contained a general prohibition of amendments, 19 constitutions a general constraint on amendments, and three constitutions even both types of general entrenchment clauses. In other words, two-thirds of today's European national constitutions are additionally protected by general entrenchment clauses.

Having demonstrated the historical and contemporary prevalence of general constitutional entrenchment clauses, the question arises whether those provisions actually fulfil their ascribed functions. So far, we know very little about the empirical effects of such provisions. Do they play any role in amendment processes and - more generally - in constitutional conflicts? Do they work as intended by their framers? Do they prolong (or rather shorten) a constitution's lifespan? Or are they merely a symbolic aspect of constitutional discourses? In other words: Do entrenchment clauses matter? ${ }^{59}$ If so, entrenchment clauses would not only be of curious textual interest, but an important aspect of constitutional reality. 